\title{
ODKRYWANIE KARAIMSKICH PIEŚNI. KARAIMSKA ŚRODA LITERACKA W WILNIE W 1932 ROKU $^{1}$
}

\author{
Stefan Gąsiorowski
}

http://orcid.org/0000-0002-5984-5337

Uniwersytet Jagielloński w Krakowie

\section{ABSTRACT \\ EXPLORING KARAIM SONGS: KARAIM LITERATURE WEDNESDAY IN VILNIUS, 1932}

This article details the history of Karaim Literature Wednesday, an event which took place on November 9, 1932 in the "Room of Konrad" of the Basilian monastery on Ostrobramska street in Vilnius. It was one of 371 popular and authoritative weekly events organized during the interwar period by the Vilnius Branch of the Polish Writers Labour Union. During this event, Hachan Seraja Szapszal - the leader of Polish Karaims - gave a lecture on the history and culture of his nation, after which several Karaim songs were sung by Walentyna and Halina Łobanosówny, accompanied by Lidia Szole on the piano. The songs were broadcast by the Vilnius Radio, and aroused great interest among the listeners. Using source material from the private archive of Józef Sulimowicz in Warsaw, I have attempted to recreate Karaim Literature Wednesday, in particular the diversity, origin and richness of Karaim songs. The annex to this article contains the original lyrics to 19 Karaim songs written in the Karaim language, most of which were sung at the event.

Keywords: Karaims, songs, Literature Wednesday, Vilnius, radio, Seraja Szapszał, interwar.

Słowa kluczowe: Karaimi, pieśni karaimskie, Środy Literackie, Wilno, radio, Seraja Szapszał, międzywojnie.

1 Rozszerzony tekst referatu pt. „Karaimska Środa Literacka w Wilnie w 1932 roku” wygłoszonego na międzynarodowej konferencji naukowej „Karei Europae Orientalis” w Poznaniu 13 I 2017 r. Dziękuję serdecznie dr Annie Sulimowicz-Keruth i Marioli Abkowicz za cenne uwagi do niniejszego tekstu. 


\section{WILEŃSKIE ŚRODY LITERACKIE. WSTĘP}

Wileńskie Środy Literackie, z racji udziału wybitnych prelegentów, regularności (odbywały się co tydzień w sezonie od października do końca maja) i zainteresowania publiczności, stały się w międzywojennej Polsce swoistym fenomenem na skalę ogólnokrajową. Organizował je Związek Zawodowy Literatów Polskich Oddział w Wilnie od lutego 1927 do czerwca 1939 roku. Powstały w 1925 roku wileński Związek Literatów początkowo nie miał swojej stałej siedziby i Środy Literackie organizowano w bibliotece Wydziału Sztuk Pięknych Uniwersytetu Stefana Batorego przy ulicy Świętej Anny 4, a od trzeciego sezonu, czyli października 1929 roku, już w stałej siedzibie związku, w tak zwanej celi Konrada w dawnym klasztorze Bazylianów przy ulicy Ostrobramskiej 9. Tak naprawdę Związek Literatów zajmował dwa pomieszczenia. W celi Konrada mieściła się Wystawa Pamiątek Mickiewiczowskich i Filomackich oraz biblioteczka, a w drugiej, większej, odbywały się środowe zebrania. Sala obrad mierzyła około 6 metrów szerokości i 12 metrów długości. Przy jednej z krótszych ścian stał podest na całą szerokość sali, na którym znajdował się duży stół, a na nim lampa z abażurem. Tam sadzano prelegenta i osobę prowadzącą spotkanie. Na sali zaś, jak w oberży, ustawiono stoły oraz stylowe, ciężkie ławy i dębowe krzesła przeznaczone dla publiczności. A więc nie było żadnych rzędów. Gdy publiczność szczególnie dopisała, dostawiano dodatkowe krzesła na środku między stołami. Po zakończeniu odczytu, przed dyskusją, podawano ciastka i herbatę. Na spotkaniach panowała swobodna, towarzyska atmosfera ${ }^{2}$.

Zgodnie z przyjętą zasadą do wygłoszenia prelekcji zapraszano ludzi wybitnych, „którzy nie tylko zaznaczyli swą obecność w kulturze polskiej, ale również osobowością i autorytetem mogli dać wzór współczesnego intelektualisty”", także z zagranicy (np. brytyjskiego pisarza Gilberta Keitha Chestertona), przy czym nie zważano na ich pochodzenie czy poglądy polityczne. Dbano również o elitarność spotkań. Obok członków Związku Literatów uczestniczyli w nich zazwyczaj wprowadzeni przez tych członków goście oraz studenci i gimnazjaliści. Młodzież uniwersytecka płaciła za wstęp 75 groszy, pozostali po złotówce. Stali goście niebędący członkami Związku mogli wykupić roczną kartę wstępu, która kosztowała 40 złotych, lub co najmniej kwartalną za 10 złotych $^{4}$.

Warto podać kilka tytułów środowych spotkań literackich i nazwiska prelegentów, aby ukazać różnorodność podejmowanych tematów. Wśród nich w kolejności chronologicznej można wymienić: „Zabytki ewangelickie i prawosławne świadectwem kultury polskiej na Ziemiach Wschodnich" (referent: Wacław Gizbert-Studnicki, archiwista i historyk; data imprezy: 18 IV 1928), „Przegląd dziejów literatury żydowskiej” (Max Eryk-Merkin, sekretarz Żydowskiego PEN Clubu; 7 V 1929),

2 J. Hernik Spalińska, Wileńskie Środy Literackie (1927-1939), Warszawa 1998, s. 18-19, $21-$ 23, 282; T. Byrski, Teatr-radio. Wspomnienia, Warszawa 1976, s. 176-177, 185.

3 J. Hernik, Wileńskie Środy Literackie, ,Akcent. Literatura i Sztuka” R. 11, 1990, nr 1/2, s. 348.

4 J. Hernik Spalińska, op. cit., s. 23-24, 50-51; T. Łopalewski, Czasy dobre i złe, Warszawa 1966, s. 115. 
„O piszących kobietach” (Zofia Nałkowska; 27 XI 1929), „Kościół a bolszewizm” (prof. Marian Zdziechowski, prezes Towarzystwa Przyjaciół Nauk w Wilnie; 3 IV 1930), „Najmłodsze Wilno literackie” (Teodor Bujnicki, Kazimierz Hałaburda, Czesław Miłosz i Jerzy Zagórski; 28 I 1931), „Kultura państw bałtyckich ze szczególnym uwzględnieniem Estonii” (Bolesław Wit-Święcicki, dziennikarz; 5 II 1931), „Podstawy i źródła hitleryzmu w kulturze Niemiec po wojnie” (Stanisław Baczyński, prof. Instytutu Europy Wschodniej; 11 V 1933), „U źródeł prawdy (rzecz o Starym Testamencie)” (ks. prof. Augustyn Jakubisiak; 14 VII 1933), „Wędrówki po więzieniach sowieckich [tytuł roboczy]" (Franciszek Olechnowicz, poeta białoruski; 4 X 1933), „Dlaczego nie czytamy książek?” (Wanda Dobaczewska i Bolesława Żynda, księgarz; 29 XI 1933), „Obrazy, dumy i gawędy z wierchowiny huculskiej” (Stanisław Vincenz; 7 III 1934), „Fragmenty etnograficzne z wyprawy kajakowej przez Irak i Indie” (Wacław Korabiewicz, lekarz; 16 XII 1936), „O plagiacie” (Karol Irzykowski; 23 II 1938) ${ }^{5}$.

Od czasu kiedy Związek zakupił fortepian, środowe spotkania często wypełniała muzyka, zapewne za sprawą Witolda Hulewicza, literata, tłumacza i działacza kulturalnego, który był współzałożycielem wileńskiego Związku Zawodowego Literatów Polskich i jego pierwszym sekretarzem, a następnie prezesem. Na tych imprezach gościło również polskie radio, Hulewicz pełnił bowiem także funkcję dyrektora programowego Rozgłośni Wileńskiej od początku jej istnienia, czyli końca listopada 1927 roku (oficjalne otwarcie 15 I 1928). Oddział wileński Polskiego Radia powstał jako piąty w Polsce i uznawano go za jeden z najlepszych w kraju. Przed mikrofon zapraszano prawie każdego, kto zaznaczył się w życiu Wilna czymś nieprzeciętnym. Miał opinię rozgłośni pluralistycznej, gdyż nadawał odczyty i pogadanki dla Białorusinów i Litwinów w ich językach, a także koncerty dla nich. Informacje, które uznawano za bardzo ważne dla słuchaczy, podawano również w językach mniejszości. Hulewicz układał audycje w cykle odpowiadające poszczególnym działom: gospodarczemu, muzycznemu czy literacko-historycznemu. Za ten ostatni był odpowiedzialny między innymi Wiktor Piotrowicz, publicysta i krytyk, członek Związku Zawodowego Literatów Polskich, a zawodowo kierownik Oddziału Wyznaniowego w Urzędzie Wojewódzkim w Wilnie ${ }^{6}$.

J. Hernik Spalińska, op. cit., s. 71, 93-94, 99-100, 117-118, 136-140, 196, 199, 204-205, 210, 266, 285.

6 Ibidem, s. 25, 85; T. Byrski, op. cit., s. 160, 162, 165, 167; S. Helsztyński, Hulewicz Witold (1895-1941) [w:] Polski Stownik Biograficzny, t. 10, Wrocław-Warszawa-Kraków 1962-1964, s. 96-97; M.J. Kwiatkowski, Narodziny polskiego radia. Radiofonia w Polsce w latach 1918-1929, Warszawa 1972, s. 272, 275; M. Paszkiewicz, Piotrowicz Wiktor (1900-1954) [w:] Polski Stownik Biograficz$n y$, t. 26, Wrocław 1981, s. 453-454; M. Kosman, Radio Wileńskie i jego miejsce w kulturze Kresów Pótnocno-Wschodnich Polski międzywojennej, „Z Dziejów Polskiej Radiofonii” 2005/2006, nr 2, s. 154-155. 


\section{KARAIMSKIE WĄTKI}

Wątki karaimskie pojawiły się podczas Wileńskich Śród Literackich kilka razy, na przykład podczas spotkania 13 grudnia 1933 roku, na którym referaty dotyczące Trok (znanej siedziby o średniowiecznym rodowodzie i ośrodka kultury karaimskiej) wygłosili historyk sztuki Stanisław Lorentz i ksiądz kanonik Wiktor Potrzebski, oraz na posiedzeniu 26 października 1938 roku, na którym architekt Jan Borowski omawiał roboty konserwatorskie prowadzone przy ruinach tamtejszego zamku. Zrozumiałe, że również zorganizowany 27 lutego 1935 roku wykład zwierzchnika Karaimów polskich, hachana Seraji Szapszała, o średniowiecznym poecie perskim Firdausim (932/942-1020/1025), autorze poematu Księga królów składającego się z 60000 wersów, również nie mógł się obejść bez tych wątków. W ramach Śród Literackich w Wilnie wieczór w pełni karaimski odbył się jednak tylko raz, a mianowicie 9 listopada 1932 roku. Miał on szczególną oprawę. Dzięki zachowanym źródłom archiwalnym przechowywanym w Dziale Rękopisów Biblioteki Litewskiej Akademii Nauk w Wilnie, prywatnym archiwom i bieżącym artykułom prasowym możemy w miarę dokładnie odtworzyć przygotowania do karaimskiej Środy Literackiej w Wilnie, jej przebieg i następstwa?

Rozmowy w sprawie jego organizacji i programu były prowadzone $\mathrm{z}$ hachanem II Rzeczypospolitej przez wspomnianego Wiktora Piotrowicza w imieniu wileńskiego Związku Literatów i tamtejszej radiostacji od początku października 1932 roku. Po wstępnej zgodzie Szapszała na współorganizowanie spotkania i wygłoszenie referatu o Karaimach Witold Hulewicz, dyrektor programowy Rozgłośni Wileńskiej i prezes Związku Zawodowego Literatów Polskich w Wilnie, wysłał 18 października 1932 roku oficjalny list z prośbą o zaakceptowanie opisanego w nim projektu programu wieczoru karaimskiego. Obok słowa wstępnego Piotrowicza znalazły się w nim referat Szapszała o historii, kulturze i tradycjach Karaimów, mający trwać 30-35 minut, oraz pieśni karaimskie. Hulewicz poinformował też Szapszała o ostatnim punkcie programu, napisał, że rozmawiał już z panią Lidią Szole ${ }^{8}$, która zgodziła

\footnotetext{
7 Zespół Seraja Szapszała. Biblioteka Litewskiej Akademii Nauk im. Wróblewskich w Wilnie, Dział Rękopisów (dalej: BLANwW, Dział Rękop.), sygn. F 143-1024; Nuty i teksty. Archiwum Józefa Sulimowicza, sygn. JSul. II.233; J. Hernik Spalińska, op. cit., s. 180-181, 206-207, 238, 294-295. Dziękuję serdecznie dr Annie Sulimowicz-Keruth za udostępnienie zasobów prywatnego archiwum na potrzeby niniejszego artykułu.

8 Lidia Szole-Karakasz (1896-1943), córka Ezry Szole (właściciela fabryki gliz papierosowych), i Kamili-Emilii z domu Łobanos (była więc stryjeczną siostrą Walentyny i Haliny Łobanosówien, o których więcej poniżej), absolwentka Wydziału Sztuk Pięknych Uniwersytetu Stefana Batorego w Wilnie i studentka Akademii Sztuk Pięknych w Paryżu, malarka, dekoratorka wnętrz, kierowniczka amatorskiego teatru karaimskiego, członek zarządu Wileńskiego Stowarzyszenia Karaimów, sekretarz Towarzystwa Miłośników Historii i Literatury Karaimskiej oraz Towarzystwa Niezależnych Artystów Plastyków w Wilnie; została zabita przez Niemców podczas „łapanki” na Żoliborzu w Warszawie. S. Gąs iorow ski, Towarzystwo Miłośników Historii i Literatury Karaimskiej w Wilnie i jego członkowie w latach 1932 1939 [w:] Karaj kiuńlari. Dziedzictwo narodu karaimskiego we współczesnej Europie, red. M. Abkowicz, H. Jankowski, współpraca I. Jaroszyńska, Wrocław 2004, s. 80; Z. Dubińska, Przez zasłonę cza$s u$, „Awazymyz. Pismo Historyczno-Społeczno-Kulturalne” 2009, nr 3, s. 8; M. Pawelec, Ptomień zgast
} 
się przygotować materiał muzyczny na to spotkanie. Prosił jedynie o zaproponowanie wykonawczyni pieśni karaimskich i akompaniatora lub przekazanie tej sprawy rozgłośni. Prezes Związku dodał też, że całe spotkanie będzie transmitowane przez radio, i zaoferował honorarium dla Szapszała w wysokości 100 złotych ${ }^{9}$.

W odpowiedzi Szapszał stwierdził, że dając zgodę na swój wykład o Karaimach, miał „na względzie audytorium składające się głównie z literatów i w ogóle inteligencji interesującej się ich religią, pochodzeniem i etnografią” oraz to, że „wykład, chociaż o charakterze popularnym, będzie wykładem zwykłego typu, obliczonym na 50-60 minut. Jeżeli zaś ma to być audycja radiowa, to oczywiście nie może ona przekraczać tego maksimum czasu", które wyznaczył Hulewicz, czyli 30-35 minut. „Może i tego być za wiele, ponieważ radiosłuchacze składają się przeważnie z ludzi całkiem nieprzygotowanych do słuchania wykładów typu uniwersyteckiego". Szapszał sugerował więc, aby przeznaczyć mu 50-60 minut na wykład i nie transmitować go przez radio, natomiast wyemitować wprowadzenie do wieczoru karaimskiego Wiktora Piotrowicza, wstęp do śpiewów Lidii Poziemskiej ${ }^{10}$ oraz recital Walentyny ${ }^{11}$

przedwcześnie. Lidia Karakasz-Szole (1896-1943), „Awazymyz. Pismo Historyczno-Społeczno-Kulturalne Karaimów" 2011, nr 1 (30), s. 12-14; U. Wróblewska, Działalność kulturalno-oświatowa Karaimów w Drugiej Rzeczypospolitej, Białystok 2015, s. 40, 51, 59, 105, 129, 130; A. Sulimowicz, Hazzan, poeta, ttumacz. W 70. rocznicę śmierci Józefa Łobanosa (1880-1947), „Awazymyz. Pismo Historyczno-Społeczno-Kulturalne Karaimów” 2017, nr 3 (56), s. 9.

9 List Witolda Hulewicza do Seraji Szapszała z 18 X 1932 r. BLANwW, Dział Rękop., sygn. F 143-1024, k. 2-2v.

10 Lidia Poziemska (1886-1952), córka Józefa Łobanosa i Emilii z domu Abkowicz, urodziła się w Trokach, skończyła gimnazjum w Petersburgu, wyszła za Alfreda Elifasa Poziemskiego, przedsiębiorcę w branży tytoniowej, z którym do 1917 r. mieszkała w Moskwie, a następnie przeniosła się do rodzinnego miasta. Tam pełniła funkcję sekretarza Rady Opieki Szkolnej przy pięcioklasowej państwowej szkole karaimskiej, zorganizowała amatorski karaimski teatr i chór, prowadziła kursy tańca towarzyskiego, uczyła gry na fortepianie i pisała wiersze. Cieszyła się wśród Karaimów wielkim autorytetem. Zmarła w Trokach, gdzie została pochowana na nowym cmentarzu karaimskim. Miała czwórkę dzieci. W kolekcji Seraja Szapszała zachował się rękopis jej wiersza pt. „Elegia”, z podaniem miejsca Nowa-Wilejka i datą: 23 II 1932 r. Dziękuję Marioli Abkowicz za wskazanie tego źródła. BLANwW, Dział Rękop., sygn. F 143-1573; Dokumentacja szkoły karaimskiej w Trokach, tamże, sygn. F 310-219, k. 64; K. Pilecki, Cień z przeszłości, „Awazymyz. Pismo Historyczno-Społeczno-Kulturalne” 2000, nr 1 (4), s. 3-7 (w aneksie jej wiersze); Z. Dubińska, op. cit., s. 8; U. Wróblewska, op. cit., s. 70.

11 Walentyna, po mężu Sulimowicz (1910-1997), córka hazzana i pisarza Józefa Łobanosa oraz Heleny z domu Ławreckiej (Ławrzeckiej), urodziła się w Moskwie, uczęszczała do szkoły karaimskiej w Trokach, ukończyła Państwowe Gimnazjum Żeńskie im. Księcia Adama Jerzego Czartoryskiego w Wilnie, w 1936 r. poślubiła halickiego Karaima Marka Sulimowicza. Była członkiem Towarzystwa Miłośników Historii i Literatury Karaimskiej w Wilnie i organizatorką zabaw karaimskich. Po II wojnie światowej zamieszkała we Wrzeszczu. Miała jednego syna - Bogusława. W. Zajączkowski, Łobanos Józef (1878-1947) [w:] Polski Stownik Biograficzny, t. 18, Wrocław-Warszawa-Kraków 1973, s. 369; U. Wróblewska, op. cit., s. 69, 72, 96, 100, 129, 169; A. Sulimowicz, op. cit., s. 9-10; M. Abkowicz, A. Sulimowic z, Nowe dane o biografii karaimskiego poety Szymona Kobeckiego, „Almanach Karaimski” 2016, nr 5, s. 18; Relacja Marioli Abkowicz z 22 II 2017 r. Korespondencja w posiadaniu autora artykułu. Zdjęcia rodziny Łobanosów i informacje o powiązaniach rodzinnych można znaleźć także w katalogu wystawy fotograficznej: M. Abkowicz, A. Sulimowicz, Karaj joltary - karaimskie drogi. Karaimi w dawnej fotografii, [Wrocław] 2010, s. 104-112. 
i Haliny ${ }^{12}$ Łobanosówien przy akompaniamencie Lidii Szole. Wreszcie prosił, aby proponowane honorarium przekazać do Wojewódzkiego Komitetu do Spraw Bezrobocia miasta Wilna ${ }^{13}$.

W nowym liście do Szapszała z 28 października 1932 roku Hulewicz uznał, że jego argumenty są zasadne, i zmienił plan karaimskiej Środy Literackiej. Otóż po zagajeniu miał przemówić kierownik Piotrowicz. Jako następne przewidziano wykonanie pieśni karaimskich poprzedzone wstępem Lidii Poziemskiej, trwające około 45 minut i transmitowane przez radio. Potem - po wyłączeniu mikrofonu - miał nastąpić około 50-minutowy wykład Szapszała. Wobec dokonanych zmian dyrektor Hulewicz obniżył również stawkę honorarium do 50 złotych, którą to kwotę zobowiązał się dostarczyć do wileńskiego Wojewódzkiego Komitetu do Spraw Bezrobocia ${ }^{14}$.

\section{KARAIMSKA ŚRODA LITERACKA}

O przebiegu karaimskiej, 169. Środy Literackiej można się dowiedzieć z prasy „Słowa” i „Kuriera Wileńskiego”. Obie gazety w rubryce Kronika kulturalna zamieściły krótkie sprawozdania. Wieczornica (wstęp dla członków zwyczajnych i członków sympatyków był bezpłatny, a dla gości wprowadzonych przez członków opłata wynosiła 1 złoty) rozpoczęła się 9 listopada 1932 roku o godzinie $20.30^{15}$. Słowo wstępne wygłosił Wiktor Piotrowicz, ,znawca wyznań wileńskich”. Zakończył je opisem „życia i działalności religijno-naukowej” Seraji Szapszała. Po nim nastąpiła część wokalna.

Złożyły się na nią pieśni karaimskie, już to smętne i zawodzące, już to wesołe i skoczne, świadczące o bogactwie motywów karaimskiej muzyki ludowej. Odśpiewały je Walentyna i Halina Łobanosówny, którym akompaniowała na fortepianie Lidia Szole. Po przerwie Jego Ekselencja Chan Seraja Bej Szapszał wygłosił obszerny odczyt, w którym opierając się na bogatym materiale historycznym, wykazał, że odwieczna kultura narodu karaimskiego w istocie swej jest odrębna i oryginalna, najważniejszymi zaś obecnie jej ośrodkami są Krym i Troki.

12 Halina Andrzejewska (1912-1986), córka Józefa Łobanosa i Heleny z domu Ławreckiej (Ławrzeckiej), urodziła się w Moskwie, uczęszczała do szkoły karaimskiej w Trokach, ukończyła Państwowe Gimnazjum im. św. Jana Kazimierza w Nowej Wilejce. W 1936 r. przyjęła prawosławie i wyszła za Kiriła Andrejewa. Po II wojnie światowej zamieszkali w Gdańsku i przyjęli nazwiko Andrzejewski. Mieli jedną córkę. W ich archiwum domowym zachowały się nuty pieśni karaimskich, zapewne z repertuaru Haliny Łobanosówny. W. Zajączkow ski, Łobanos Józef..., s. 369; U. Wróblew ska, op. cit., s. 69, 72, 97; A. Sulimowicz, op. cit., s. 9. Relacja Marioli Abkowicz z 22 II 2017 r. Korespondencja w posiadaniu autora artykułu.

13 List S. Szapszała do W. Hulewicza z 21 X 1932 r. (?) Brudnopis, BLANwW, Dział Rękop., sygn. F 143-1024, k. 1, 12.

14 List W. Hulewicza do S. Szapszała z 28 X 1932 r., BLANwW, Dział Rękop., sygn. F 143-1024, k. 4.

15 Kronika Wileńska, rubryka: Zebrania i Odczyty, „Słowo”, 8 XI 1932, nr 281, s. 3. 
Odczyt ilustrowały obficie przeźrocza. Środa ta odbyła się przy wyjątkowo licznym audytorium ${ }^{16}$.

Redakcja „Kuriera Wileńskiego” wyrażała z kolei uznanie dla Zarządu Związku Literatów za urządzenie tego wieczoru, nazywając go ,regionalizmem w najlepszym rozumieniu”. I dalej: „Znakomita większość zebranych na tej Środzie po raz pierwszy usłyszała coś nie tylko niezmiernie interesującego, ale konkretnego, z tak autorytatywnego źródła"17. Bezpośrednia transmisja radiowa z wieczoru karaimskiego została wyemitowana przez Radio Wileńskie na żywo w godzinach od 20.50 do $21.30^{18}$.

Jak napisał w swojej książce Narodziny polskiego radia profesor Maciej Józef Kwiatkowski (1920-1994), dziennikarz radiowy i historyk radia, dokumenty i archiwa przedwojennego Polskiego Radia zostały w dużej mierze zniszczone w okresie drugiej wojny światowej, zarówno w centrali w Warszawie, gdzie znajdowały się najważniejsze materiały archiwalne, jak i w rozgłośniach w Baranowiczach, Lwowie i Wilnie. W stolicy odbywało się to etapami. Najpierw część materiałów spalili sami pracownicy radia, jeszcze we wrześniu 1939 roku, aby nie dostały się w ręce Niemców. Drugą część, wraz z biblioteką i nutoteką, zniszczył okupant. Trzecia, ocalona wcześniej przez pracowników radia, spłonęła podczas powstania warszawskiego. Nie zachowały się również teksty audycji, z wyjątkiem tych wydrukowanych w prasie lub skopiowanych przez osoby prywatne. Także nieliczne płytowe nagrania audycji zachowały się w prywatnych rękach. Dotyczy to jednak tylko tych programów, które zostały wyemitowane po roku 1934, kiedy w Polskim Radiu wprowadzono urządzenia do nagrywania na miękkich płytach ${ }^{19}$.

\section{KARAIMSKA PIEŚŃ}

Nieco światła na to, jak wyglądał recital pieśni karaimskich, rzucają zachowane materiały rękopiśmienne z Archiwum Józefa Sulimowicza, znajdujące się w rękach prywatnych. W całości zachowało się wprowadzenie do recitalu (rękopis i maszynopis), które wygłosiła zapewne Lidia Poziemska, jakkolwiek jego rękopis został sporządzony ręką Walentyny Łobanosówny (po mężu Sulimowicz), jak to określono w dopisku pod tekstem. Wersja rękopiśmienna jest znacznie obszerniejsza w porównaniu z maszynopisem, który został skrócony prawdopodobnie w związku z wymogami czasowymi. Warto obie wersje tekstu przytoczyć w całości. Wprowadzenie napisane na maszynie, przedstawione na karaimskiej Środzie Literackiej, brzmiało następująco:

Smutna jest pieśń karaimska. Jej tony minorowe wkradają się do serca, budzą do życia najskrytsze uczucia. Charakter tej pieśni jest w ścisłym związku z dawnym stanowiskiem ko-

16 W., Środa karaimska, „Słowo”, 11 XI 1932, nr 284, s. 2.

17 „Kurier Wileński”, 15 XI 1932. Za: J. Hernik Spalińska, op. cit., s. 181.

18 Radjo Wileńskie, „Słowo”, 9 XI 1932, nr 282, s. 4.

19 M.J. Kwiatkowski, op. cit., s. 18-19. 
biety karaimskiej w społeczeństwie. Karaimi, podług obyczajów Wschodu, ukrywali kobietę przed spojrzeniem mężczyzny i zamykali ją w osobnej części domu, przeznaczonej tylko dla niewiast. Mężczyzna nigdy nie widział otwartego oblicza kobiety i czatował na chwile, kiedy niewiasta wychodziła ku źródłu po wodę. Uchylała ona wtedy na krótką chwilę zasłony i tej jedynej chwili starczało, aby miłość ogarnęła se[r]ca obojga. Potęgowana w ukryciu znajdowała ukojenie w melodji przepojonej niezgłębioną tęsknotą do ukochanej. Siłę tęsknoty barwnie charakteryzuje pieśń miłosna, którą śpiewa młodzieniec, a słowa jej brzmią, jak następuje: „Gdyby wody Morza Czarnego były atramentem, a wszystkie topole Krymu - piórami, nie wystarczyłoby tego, aby opisać tęsknotę moją do Ciebie, o, ukochana!”. Pieśni niemiłosne natomiast mają charakter weselszy, śpiewane bowiem były w czasie zabaw dziecięcych. Melodje taneczne, w zależności od charakteru tańca, przechodzą od poważnych do nader żywych, a nawet brawurowych ${ }^{20}$.

Pierwotna, rękopiśmienna wersja wstępu do pieśni karaimskich jest mniej dopracowana literacko, ale bogata w dodatkowe, cenne szczegóły:

\section{O pieśni karaimskiej}

Smutna jest pieśń karaimska. Melodja jej tonów minorowych wkrada się do serca, budzi do życia najskrytsze uczucia i napełnia duszę niewypowiedzialnym smutkiem. Charakter te[j]że stoi bezpośrednio w ścisłym związku z dawnym stanowiskiem kobiety karaimskiej w społeczeństwie. Karaimi, podług obyczajów Wschodu, ukrywali kobietę przed spojrzeniem mężczyzny i zamykali ją w osobnej części domu, przeznaczonej tylko dla niewiast. Mężczyzna nigdy nie widział otwartego oblicza kobiety i czatował na chwile, kiedy niewiasta wychodziła ku źródłu po wodę. Czy to wypadkowo, czy też świadomie uchylała ona na jedną krótką chwilę zasłonę i tej jedynej chwili wystarczało, aby miłość ogarnęła serca obojga. Potęgowana w ukryciu znajdowała ukojenie w melodji przepojonej niezgłębioną tęsknotą do ukochanej. Siłę tęsknoty barwnie charakteryzuje pieśń miłosna, którą śpiewa młodzieniec, a słowa jej brzmią, jak następuje: „Gdyby wody Morza Czarnego były atramentem, a wszystkie topole Krymu - piórami, nie wystarczyłoby tego, aby opisać tęsknotę moją do Ciebie, o!, ukochana!”. Jak surowo był przestrzegany obyczaj ukrywania niewiast, mówi znany pisarz rosyjski drugiej połowy XIX-go stulecia - Atanazy Czużbiński, iż jedyny raz w życiu udało mu się widzieć Karaimkę.

Zaś pieśni niemiłosne natomiast noszą charakter weselszy, śpiewane bowiem były w czasie zabaw dziecięcych. Treść pieśni składa się z porównania poetyckiego, np.: „Spójrz na gwiazdy i księżyc, a także na dziewczynę stojącą na dachu. Czyż oczy jej nie są to gwiazdy, a czoło jak księżyc? A włosy jej jak welon nocy. Lub też posłuchaj cudownego śpiewu słowika i głosu ukochanego dziewczęcia. Czyż głos ten nie jest tak cudowny jak głos słowika?”. Kołysankę śpiewa matka, wdowa wojaka, Karaimka trocka, nad kolebką syna, wróż[y] ona mu świetną przyszłość, powierzając jego los Bogu: „Pamiętaj o dwu miastach świa[ta] świętych - o Syonie i o Trokach".

Siłą ewolucji, wpływu kultury zachodniej i emancypacji, obyczaje narodów wschodnich uległy zmianie. Kobieta została wyzwolona, lecz pieśń pozostała i przechodząc od pokolenia do pokolenia, dotarła do nas, współczesnych Karaimów. Zachowała ona dla nas swój urok pierwotny i budzi w sercach naszy[ch] głębokie zrozumienie i uznanie. Co zaś tyczy się melodij tanecznych, to w zależności od charakteru tańca przechodzi on od poważnych do nader żywych, a nawet brawurowych ${ }^{21}$.

20 Nuty i teksty, Archiwum Józefa Sulimowicza, sygn. JSul. II.233, bez paginacji.

${ }^{21}$ Ibidem. Ten sam tekst znajduje się również w kolekcji Seraji Szapszała w Bibliotece Wróblewskich w Wilnie, za jego wskazanie dziękuję Marioli Abkowicz. Lidia Poziemska, O pieśni karaimskiej. BLANwW, Dział Rękop., sygn. F 143-1536. 
Co więcej, obok wprowadzenia zachował się także „Program audycji muzyki i pieśni karaimskich" przygotowany przez Lidię Szole, która się pod nim podpisała i podała numer swojego telefonu. Składał się on z 15 utworów. Podano w nim tytuły kompozycji w języku karaimskim i polskim. Oprócz pięciu utworów wszystkim towarzyszyły pieśni. W większości z nich tytuły stanowiły pierwsze słowa pieśni. Ułożono je w maszynopisie według następującego porządku:

1. Gidyn bołutłar... - Poszły chmury (śpiew)

2. Czippiim ${ }^{22} \ldots-$ Weselne potrawy (śpiew)

3. Syja perczem... - Czarna czupryna (muzyka)

4. Czubuk...- Smyczek (śpiew)

5. Kujasz endi... - Zaszło słońce (kołysanka) (śpiew)

6. Hor, hor, adaman... - (muzyka)

7. Üwlariniź... - Wasz dom (śpiew)

8. Demerdżiler... - Kowale (śpiew)

9. Ben bostandży... - (muzyka)

10. Öksek minare ${ }^{23} \ldots-$ Brwi jak łuki (śpiew)

11. Inkiermanda... - Na stepach Akkermanu (śpiew)

12. Elif dedim, be dedim... - Powiedziałem A, powiedziałem B (muzyka)

13. Bir örkiende... - Na jednej łodydze pięć harbuzów (śpiew)

14. Mużhuł ${ }^{24}$ kieliń... - Smutna narzeczona (śpiew)

15. Chajtarma... - Narodowy taniec karaimski (muzyka ${ }^{25}$

Być może kolejność i tytuły tych pieśni uległy jednak zmianie w ustaleniach końcowych, zapewne przy udziale samego Seraji Szapszała, bezpośrednio przed koncertem, ponieważ na następnych kartkach maszynopisów zachowały się krótkie jednozdaniowe wprowadzenia do sześciu pierwszych pieśni oraz teksty utworów zestawione $\mathrm{w}$ innym cyklu, a ponadto nuty niektórych $\mathrm{z}$ nich. W nowym układzie na pierwszym miejscu pojawił się Czubuk z opisem: „Piosenka miłosna, którą śpiewa młodzieniec do swej ukochanej, brzmi następująco: Tak jak pręt smyczka i włosie stanowią nierozerwalną całość - tak ty jesteś moją, a jam twój”. Jako drugi podano pieśń Üwlariniź ze wstępem: „Piosenka z dzikich stepów nogajskich. Dzielny młodzieniec śpiewa w te słowa: Wysoko stoi twój dom i trudno mi się do niego dostać. Jeśli nie uda mi się dostać od ciebie czegoś na pamiątkę, nie zaznam nigdy spokoju”. Na trzecim miejscu pojawił się utwór z miejsca pierwszego pod tytułem Gidyn boluttar z dość enigmatycznym opisem: „Rzewna piosenka z charakterystycznym beztroskim refrenem", a następnie wcześniej nieprzewidziany Karanfil (goździk) określony jako: „Wesoła piosenka, w której młodzieniec porównuje swoją ukochaną do kwiatu

22 Ta popularna wśród Karaimów piosenka znana była też pod dosłownym tytułem Mój kurczaczku. Za: dr A. Sulimowicz-Keruth.

${ }^{23}$ Polska wersja tytułu tej piosenki jest prawdopodobnie tłumaczeniem jej refrenu, ponieważ Öksek minare znaczy dosłownie ,wysoki minaret”. Za: dr A. Sulimowicz-Keruth.

24 Winno być Muzhut. Za: dr A. Sulimowicz-Keruth.

25 Według dr A. Sulimowicz-Keruth w zestawieniu tym przeważają utwory krymskie, tylko tytuły trzech z nich zostały zapisane w wymowie trockiej, a mianowicie: Üwlariniź (po krymsku byłoby Evleriniz), Kujasz endi (po krymsku - Jukła uwłum) i Muzhut kieliń. Nuty i teksty, Archiwum Józefa Sulimowicza, sygn. JSul. II.233, bez paginacji. 
goździka". Dalej znalazł się utwór z drugiego miejsca zatytułowany Czipiim (Weselne potrawy), który anonsowało zdanie: „Zakochany młodzieniec porównuje swą słodką Czippiim do przysmaków uczty weselnej”. Wreszcie następował ostatni zachowany w tym nowym zestawieniu Muzhut kieliń, czyli: „Pieśń weselna o smutnej narzeczonej. Melodia [...]" (dalej tekst nieczytelny ${ }^{26}$.

Oprócz tego, jak już napisano, zachowały się teksty kilkunastu piosenek (w języku karaimskim w alfabecie łacińskim lub cyrylicą) i nuty. Część nie znalazła się w żadnym z wcześniejszych zestawień. Należą do nich: Czubuk (tekst w trzech wersjach i nuty), Inkiermanda (tekst w dwóch wersjach, w tym autograf S. Szapszała i nuty), Demerdżiler (tekst w dwóch wersjach i nuty), Üwlariniź (tekst), Irakdan (tekst i nuty), Fykyrynyn turkysy (tekst), Dülberin turkysy (tekst), Kelin awasy (tekst i nuty), Kielin awasy (dost kyzłar jyrtajtar) (tekst), Eki-de kezin (tekst), Szarduwan (sewincz czeszmesy) (tekst), Szerbiet (nedawanyn jasły künlarinde jyrtahan tirki) (tekst), Kaleden-kelee (tekst), Achszam (tekst), Dżankoz-gołowa (tekst), Karasywnyn dört koszesy (tekst), Gidin bułuttar gidin (tekst), Ycz karanfil aszładym (tekst), Elif dedim, be dedim (tekst), Jazha czyhsam (tekst), Czipiim (tekst - autograf S. Szapszała), Kujasz endi (kołysanka; nuty), Meń urusztan (tekst, utwór J. Łobanosa?), Alim (tekst), Port Artur (tekst) ${ }^{27}$. To zapewne z tego końcowego zestawienia pochodziły piosenki zaprezentowane na karaimskiej Środzie Literackiej.

Jak wynika z dopisku na jednej z zachowanych archiwalnych kartek, pierwotny dobór najbardziej popularnych karaimskich pieśni został prawdopodobnie zaczerpnięty z artykułu opublikowanego w czasopiśmie „Karaimskaâ žizn”” w 1911 roku. Autor tego krótkiego, trzystronicowego tekstu, podpisany jako Konuszmadżi, nawiązał do publikacji Karaimsko-tatarskie narodowe pieśni Krymu, która ukazała się wówczas w języku rosyjskim w Petersburgu. Znalazło się w niej dziewięć popularnych karaimskich pieśni: Karasubenym, Czipiim, Ben bu gidze, Kynaly parmak, Iraktan senny gerdym, Port Artur, Karga, Jazga czyksam ew-alsam i Bakczysaraj chan saraj. Jak wynika z tego zestawienia, podczas opisywanego karaimskiego wieczorku rozważano wykorzystanie jedynie czterech pieśni, a mianowicie Czipiim, Iraktan senny gerdym, Port-Artur i Jazga czyksam ew-alsam. W swoim artykule Konuszmadżi zauważył duże podobieństwo pieśni karaimskich do tatarskich i rozwinął rozważania na temat pochodzenia Karaimów oraz wzajemnych relacji karaimsko-tatarskich na Krymie. Nie rozstrzygnął jednak, czy pierwotnymi autorami omawianych utworów byli Tatarzy czy Karaimi, bowiem rozróżnienie to byłoby bardzo trudne z uwagi na bliskie kontakty obu nacji prawie we wszystkich sferach ich życia na tym terenie i posługiwanie się przez nie tym samym językiem tatarsko-kipczackim. O wiele większe trudności sprawiłoby odnalezienie autorów muzyki do tych pieśni i zapisu nutowego. Niemniej w opisywanym artykule wskazano na wielką wartość pieśni dla kultury i etnografii Karaimów oraz zachęcono czytelników czasopisma „Karaimskaâ žizn”" do nadsyłania ich tekstów i zapisów nutowych ${ }^{28}$. Apel ten nie

26 Ibidem.

27 Ibidem.

28 Konušmadži, Izučenie karaimskoj pěsni, „Karaimskaâ žizn”,, Kniga 1, 1911 s. 59-61. 
pozostał bez odpowiedzi. Jeszcze w 1911 roku opublikowano w tym czasopiśmie teksty dwóch pieśni karaimskich autorstwa Szymona Kobeckiego (1857-1933), znanego poety karaimskiego, oraz teksty dwóch pieśni i nuty do nich Samuela Szemariewicza Pigita (1849-1911), hazzana jekaterynosławskiego i pisarza, a w roku następnym anonimową, komiczną pieśń eupatoryjskiego cukiernika Kara-Moszu opartą na motywach Czipiim, znaną pieśń Irakdan seny I.È. Duvana-Torcova wraz z zapisem nutowym E.M. Rofe oraz artykulik K. Egiza o karaimskich pieśniach z tekstem utworu Port Artur i nutami do dwóch kolejnych: Kek Kegyrgyn i Juskjudar ${ }^{29}$. Warto może też dodać, że teksty i nuty karaimskich pieśni pojawiły się również w kontynuatorce czasopisma „Karaimskaâ žizn’” wychodzącym w latach 1913-1914 periodyku „Karaimskoe Slovo” oraz wydawanej w okresie międzywojennym „Myśli Karaimskiej”30.

\section{KARAIMSKA HISTORIA I KULTURA. ECHA KARAIMSKIEJ ŚRODY}

Wracając do omówionych wyżej materiałów (tekstów piosenek i nut) odnoszących się do karaimskiej Środy Literackiej, nie można nie zauważyć, że wśród nich zachował się również fragment strony maszynopisu referatu, zapewne autorstwa Seraji Szapszała, który został wygłoszony podczas tego wydarzenia. Brzmi on następująco:

[...] zasymilowany, lecz przeniosła się na Półwysep Krymski.

Język karaimski należy do wielkiej rodziny języków tiurkskich ${ }^{31}$. Dzieje Karaimów w Polsce sięgają według zapisków roku 1398, w którym W.Ks. litewski Witold przywiózł z wypraw krymskich 383 rodziny karaimskie i osadził w Trokach ${ }^{32}$. Byli to wojskowi ${ }^{33}$, ogrodnicy i sadownicy, częściowo jeńcy, częściowo osadnicy dobrowolni.

Osadzeni w nowej ojczyźnie nie stracili kontaktu z Krymem.

Przywiózłszy ze sobą Biblję i modlitewniki, pielęgnowali gorliwie tradycje narodowe, a łączność z ojczyzną przez licznych kupców tatarskich wiązała silną nicią te dwa tak dalekie ośrodki tego narodu. Chcąc przywiązać Karaimów do ziemi, Witold uwolnił ich od wszelkich

29 S.A. Kobeckìj, Kolybel'naâ piěsnâ, „Karaimskâ žizn””, Kniga 3/4, 1911 s. 19-20; idem, Kadril', „Karaimskaâ žizn””, Kniga 5/6, 1911, s. 80-81; Pěsni S. ̌́. Pigita, „Karaimskaâ žizn””, Kniga 5/6, 1911, s. 15-16; Pièsnâ evpatorìjskago pirožnika Kara-Mošu, „Karaimskâ žizn””, Kniga 8/9, 1912, s. 58; , ,Irakdan' seny”..., „Karaimskaâ žizn””, Kniga 10/11, 1912, s. 11-12; K. Egiz', Karaimskiâ pěsni, „Karaimskaâ žizn””, Kniga 10/11, 1912 s. 13-15.

30 M.P., Sagyšlar', „Karaimskoe Slovo” 1914, No. 9/10, s. 13-14; I.-ski [A. Zajączkowski], Karaimskie kotysanki. (Z cyklu „O Karaimskiej Poezji Ludowej”), „Myśl Karaimska” R. 2, 1925, z. 2, s. $5-10$.

31 Obecnie określa się je mianem języków turkijskich. M. Németh, Zwięzła gramatyka języka zachodniokaraimskiego z ćwiczeniami, Poznań 2011, s. 11.

32 W tym miejscu obok udowodnionych faktów, czyli sprowadzenia Karaimów przez księcia Witolda do Trok z wyprawy na Krym, dodano niepotwierdzoną liczbę 383 rodzin karaimskich, która została zaczerpnięta prawdopodobnie z pracy: T. Czacki, Rozprawa o Żydach i Karaitach, Kraków 1860, s. 143. Zob.: S. Gąsiorowski, Karaimi w Koronie i na Litwie w XV-XVIII wieku, Kraków-Budapeszt 2008, s. 166, 168-171.

33 Nie ma na to dowodów, że Karaimi parali się wówczas rzemiosłem wojennym. Zob. S. Gąsiorow ski, Karaimi w Koronie i na Litwie..., s. 168-169, 325, 327-342. 
ciężarów i podatków, w zamian za co zobowiązał ich do obrony granic ${ }^{34}$. Załogi karaimskie stały w Trokach, Birżanach ${ }^{35}$ [sic!], Sałatach, Poniewieżu, Nowem Mieście, Szatach itd. ${ }^{36}$, tworząc wyboro[... $]^{37}$.

Jak już wspomniano, referat Szapszała nie był transmitowany przez radio, a jego pełny tekst prawdopodobnie się nie zachował. Mimo to powszechnie znane są poglądy i wiedza hachana na temat dziejów Karaimów na terenie Litwy, którym wyraz dał w licznych przemówieniach, rękopisach i publikacjach.

Już na drugi dzień po karaimskiej środzie literackiej dyrektor Hulewicz wysłał list do Szapszała, donosząc, że zgodnie z jego życzeniem wpłacono w tym dniu do redakcji „Słowa” kwotę 50 złotych na cele Wojewódzkiego Komitetu do Spraw Bezrobocia miasta Wilna i w kolejnym numerze tego pisma powinno się ukazać odpowiednie pokwitowanie. Jednocześnie poprosił hachana, aby zechciał ofiarować związkowi literatów własną fotografię. Pisał, że ,byłaby to dla nich cenna i miła pamiątka pięknego wczorajszego wieczoru, która ozdobiłaby ścianę ich siedziby" 38 . Byliby również specjalnie wdzięczni za wpisanie na fotografii kilku słów dla tegoż związku ${ }^{39}$.

Faktycznie w wileńskim piśmie „Słowo” z 11 listopada 1932 roku w rubryce Ofiary zamieszczonej na końcu gazety ukazała się notka następującej treści: „Związek Zawodowy Literatów składa na życzenie J.E. Hachana Seraja Bei Szapszała oddany do Jego dyspozycji dochód ze Środy Karaimskiej - na rzecz Wojewódzkiego Komitetu do spraw bezrobocia w Wilnie - zł 50.00"40.

W odpowiedzi na list Hulewicza Szapszał podziękował za przekazanie 50 złotych na rzecz bezrobotnych, wyrażając wspólnie z pozostałymi uczestnikami Środy Karaimskiej radość, że przyczynili się do pomocy ich biednym bezrobotnym braciom. „Może ten grosz ofiarny - pisał hachan - dzięki Panu Dyrektorowi zmniejszył choć odrobinę ilość łaknących łyżki strawy, za co niech Bóg Najwyższy Go wynagrodzi”" do sali Związku Zawodowego Literatów Polskich Szapszał nie mógł zadośćuczynić prośbie, ponieważ nie posiadał odpowiedniej fotografii. Przyrzekł, że ją dostarczy ze stosownym napisem, gdy się na nią ,zdobędzie"42.

${ }^{34}$ To niepotwierdzona źródłowo informacja. Ibidem, s. 168-169.

35 Chodziło zapewne o Birże.

36 To również niepotwierdzona informacja. Według zachowanych źródeł Karaimi osiedlili się w tych miejscowościach dopiero w XVI-XVII w. S. Gąsiorowski, Karaimi w Koronie i na Litwie..., s. 168-169, 202-213.

37 W tekście zachowano oryginalną ortografię. Nuty i teksty, Archiwum Józefa Sulimowicza, sygn. JSul. II.233, bez paginacji.

38 List W. Hulewicza do S. Szapszała z 10 XI 1932 r., BLANwW, Dział Rękop., sygn. F 143-1024, k. 5 .

39 Ibidem.

40 Ofiary, „Słowo”, 11 XI 1932, nr 284, s. 4.

41 List S. Szapszała do W. Hulewicza z 11 XI 1932 r., BLANwW, Dział Rękop., sygn. F 143-1024, k. 6 .

42 Ibidem. 
W kolejnym liście do Szapszała z 5 grudnia tego roku Hulewicz przesłał w załączniku dwa pisma od radiosłuchaczy z Wilna do miejscowego kierownika rozgłośni, które były echem transmitowanej przez radio środy karaimskiej. Pierwszy z nich, Wiktor Szawrejko, napisał, że jest stałym słuchaczem śród literackich i z zapałem przysłuchiwał się ostatniej z nich, poświęconej muzyce karaimskiej.

Było to coś pięknego - napisał - i coś niezwykłego! Zachwycony jestem śliczną kołysanką w wykonaniu chóru. Słuchałem ją z zapartym tchem, gdyż wiedziałem, że po raz drugi już jej nie usłyszę! O jakże wtedy żałowałem, że nie była to płyta gramofonowa, o którą mógłbym w koncercie życzeń prosić.

Lecz tu, o dziwo! Ku mojemu wielkiemu zdziwieniu słyszę kochany Pański głos [chodzi o Witolda Hulewicza - S.G.]! Prosi Pan w imieniu uczestników Środy o ponowne wykonanie dwu ostatnich pieśni. Jakże byłem szczęśliwy, gdy oto ponownie mogłem rozkoszować się przepiękną melodią kołysanki.

Żałuję tylko bardzo, żeśmy nie słyszeli głosu Dostojnego Przedstawiciela władzy ówczesnej Karaimów. Bo przecież chciało się słyszeć człowieka tak wielkiego i wybitnego ${ }^{43}$.

Drugi list do wileńskiego radia napisała Emilia Rutska, która stwierdziła:

Ogromnie pożądane są transmisje tego rodzaju... i bardziej żałuję, że nie dano odczytu J.E. Hachana Saraja Bej Szapszała, chociaż piosenki były ładne i wykonane zupełnie dobrze, jednak wolałabym usłyszeć coś o zwyczajach i życiu Karaimów. A może kiedykolwiek [dyrekcja radia - S.G.] zaprosi przed mikrofon... Szapszała, aby powtórzył swój odczyt ${ }^{44}$.

Dużym zainteresowaniem pieśniami karaimskimi należy tłumaczyć fakt, że audycja ze Środy Karaimskiej została powtórzona, i to zapewne nieraz, w tym także w rozgłośni warszawskiej, choć w okrojonej formie, dokładnie 15 lipca 1934 roku w niedzielę, w godzinach od 14.00 do $14.20^{45}$.

Na tym współpraca Szapszała z wileńską rozgłośnią się nie zakończyła. Zachował się bowiem list z 3 lutego 1936 roku od Haliny Hohendlingerówny, niegdyś aktorki, a wówczas stosunkowo nowej kierowniczki literackiej i reżyserki radia w Wilnie. Kierowniczka zwróciła się do hachana z prośbą o przejrzenie maszynopisu scenariusza przygotowywanej właśnie do emisji audycji radiowej, która ma być nadana na całą Polskę. Była to migawka z życia Karaimów pod tytułem Wesele Attynkyz. Poprosiła ona Szapszała o sprawdzenie, czy nie ma w nim jakichś błędów lub nieścisłości, a w razie znalezienia uchybień - o zaznaczenie na marginesie, ponieważ pracownicy radia nie chcieli „wobec całej Polski przedstawić obrzędów karaimskich w fałszywym ujęciu" ${ }^{46}$. Prosiła też o pośpiech, gdyż audycja miała być nadana 9 lutego i pracownicy musieli jak najprędzej zacząć próby. Chciała, aby Szapszał

${ }^{43}$ List W. Hulewicza do S. Szapszała z 5 XII 1932 r., BLANwW, Dział Rękop., sygn. F 143-1024, k. 7.

44 Ibidem, k. 9.

45 [Program radiowy], „Kurjer Warszawski”, 15 VII 1934, nr 192, s. 7. W tym miejscu dziękuję dr Annie Sulimowicz-Keruth za wskazanie mi tej informacji.

46 List H. Hohendlingerówny do S. Szapszała z 3 II 1936 r., BLANwW, Dział Rękop., sygn. F 1431024, k. 11. 
przejrzał maszynopis do środy. W południe w tym dniu mieli kogoś przysłać do hachana po scenariusz ${ }^{47}$.

Niestety brak dalszych informacji o losach scenariusza wspomnianej audycji, nie wiadomo również, czy hachan w czymkolwiek pomógł. Na podstawie dostępnych źródeł można przypuszczać, że Seraja Szapszał nie wystąpił w radiu wileńskim. Nie udało się też dotrzeć do archiwaliów wileńskiej rozgłośni ani odszukać zapisu koncertu karaimskich pieśni z przedstawionej Środy Literackiej.

\section{PODSUMOWANIE}

Zainteresowanie karaimskimi pieśniami, które można podzielić na liturgiczne, paraliturgiczne, obrzędowe i świeckie, nie było w Polsce zbyt duże. Obok samych Karaimów w okresie dwudziestolecia międzywojennego interesował się nimi właściwie tylko Tadeusz Kowalski (1889-1948), wybitny orientalista, profesor Uniwersytetu Jagiellońskiego i sekretarz generalny Polskiej Akademii Umiejętności ${ }^{48}$. Od wielu lat temat ten jest opracowywany przez litewską uczoną, z pochodzenia Karaimkę, doktor Karinę Firkovičiūtė, która swoje badania publikuje nie tylko w rodzimym języku, lecz także po polsku, angielsku i rosyjsku ${ }^{49}$. Ostatnio wydała w Polsce trójjęzyczną osobną książkę o karaimskich pieśniach ${ }^{50}$. Wśród utworów w niej zawartych nie ma jednak tych, które zostały przedstawione na karaimskiej Środzie Literackiej. Stąd wydaje się zasadne opublikowanie w aneksie do niniejszego artykułu 19 zachowanych oryginalnych tekstów pieśni karaimskich spisanych w języku karaimskim, z których większość została odśpiewana na opisywanej imprezie.

Konkludując, należy stwierdzić, że karaimska Środa Literacka w Wilnie w 1932 roku stała się wielką promocją historii i kultury Karaimów, a także rozpropagowała na Wileńszczyźnie i zapewne w całej Polsce okresu międzywojennego różnorodność i piękno ich pieśni ludowych. Wielka szkoda, że nie zachowało się żadne nagranie pieśni karaimskich śpiewanych przez Walentynę i Halinę Łobanosówny przy akompaniamencie fortepianowym Lidii Szole ani cały zapis tekstu wygłoszonego przez hachana hadży Seraję Szapszała. Pełne opracowanie dziejów muzyki karaimskiej czeka nadal na swoich badaczy. Karaimska Środa Literacka jest jednak dowodem na wielkie bogactwo unikatowej kultury karaimskiej, której wartość nie została jeszcze do końca rozpoznana.

47 Ibidem.

48 T. Kowalski, Pieśni obrzędowe w narzeczu Karaimów z Trok, „Rocznik Orientalistyczny” 1925, nr 3, s. 216-254; idem, Karaimische Texte im Dialekt von Troki. Teksty karaimskie w narzeczu trockim, Kraków 1929 (Prace Komisji Orjentalistycznej Polskiej Akademii Umiejętności; 11).

49 Wśród nich można wyróżnić m.in.: K. Firkovičiūtè, Nowe badania nad muzycznym dziedzictwem litewskich Karaimów [w:] Karaj kiuńlari. Dziedzictwo narodu karaimskiego..., s. 41-45; eadem, Muzyka w kulturze karaimskiej [w:] Karaimi, red. B. Machul-Telus, Warszawa 2012, s. 73-91.

50 K. Firkovičiūtè, Życie w pieśni karaimskiej. Life in Karaim Songs. Gyvenimas karaimu dainose. Tirlik karaj jyrlarynda, [Wrocław] 2016. 


\section{BIBLIOGRAFIA}

\section{Źródła archiwalne}

Archiwum Józefa Sulimowicza

sygn. JSul. II.233. Nuty i teksty.

Biblioteka Litewskiej Akademii Nauk im. Wróblewskich w Wilnie, Dział Rękopisów

Zespół Seraja Szapszał, sygn. F 143-1024, F 143-1536, F 143-1573.

Dokumentacja szkoły karaimskiej w Trokach, sygn. F. 310-219.

Relacja Marioli Abkowicz z 22 II 2017 roku [korespondencja w posiadaniu autora artykułu]

\section{Źródła wydane}

Byrski T., Teatr-radio. Wspomnienia, Warszawa 1976.

Dubińska Z., Przez zasłone czasu, „Awazymyz. Pismo Historyczno-Społeczno-Kulturalne” 2009, nr 3, s. 8-12.

Egiz’ K., Karaimskiâ pěsni, „Karaimskaâ žizn’”, Kniga 10/11, 1912, s. 13-15.

„Irakdan 'seny”..., „Karaimskaâ žizn””, Kniga 10/11, 1912 s. 11-12.

Kobeckìj S.A., Kadril“, „Karaimskaâ žizn””, Kniga 5/6, 1911, s. 80-81.

Kobeckìj S.A., Kolybel "naâ piěsnâ, „Karaimskaâ žizn””, Kniga 3/4, 1911, s. 19-20.

Konušmadži, Izučenie karaimskoj pěsni, „Karaimskaâ žizn””, Kniga 1, 1991, s. 59-61.

Kronika Wileńska, rubryka: Zebrania i Odczyty, „Słowo”, 8 XI 1932, nr 281, s. 3.

Łopalewski T., Czasy dobre i złe, Warszawa 1966.

M.P., Sagyšlar’, „Karaimskoe Slovo”, No. 9/10, 1914, s. 13-14.

Ofiary, „Słowo”, 11 XI 1932, nr 284, s. 4.

Pěsni S.Š. Pigita, „Karaimskaâ žizn’”, Kniga 5/6, 1911, s. 15-16.

Piěsnâ evpatorìjskago pirožnika Kara-Mošu, „Karaimskaâ žizn'”, Kniga 8/9, 1912, s. 58.

Pilecki K., Cień z przeszłości, „Awazymyz. Pismo Historyczno-Społeczno-Kulturalne” 2000, nr 1 (4), s. 3-7.

[Program radiowy], „Kurjer Warszawski”, 15 VII 1934, nr 192, s. 7.

Radjo Wileńskie, „Słowo”, 9 XI 1932, nr 282, s. 4.

W., Środa karaimska, ,Słowo”, 11 XI 1932, nr 284, s. 2.

\section{Opracowania}

Abkowicz M., Sulimowicz A., Karaj jołtary - karaimskie drogi. Karaimi w dawnej fotografii, [Wrocław] 2010.

Abkowicz M., Sulimowicz A., Nowe dane o biografii karaimskiego poety Szymona Kobeckiego, „Almanach Karaimski” 2016, nr 5, s. 7-33.

Czacki T., Rozprawa o Żydach i Karaitach, Kraków 1860.

Firkovičiūtè K., Muzyka w kulturze karaimskiej [w:] Karaimi, red. B. Machul-Telus, Warszawa 2012, s. 73-91.

Firkovičiūtè K., Nowe badania nad muzycznym dziedzictwem litewskich Karaimów [w:] Karaj kiuńlari. Dziedzictwo narodu karaimskiego we współczesnej Europie, red. M. Abkowicz, H. Jankowski, współpraca I. Jaroszyńska, Wrocław 2004, s. 41-45. 
Firkovičiūtè K., Życie w pieśni karaimskiej. Life in Karaim Songs. Gyvenimas karaimu dainose. Tirlik karaj jyrlarynda, [Wrocław] 2016.

Gąsiorowski S., Karaimi w Koronie i na Litwie w XV-XVIII wieku, Kraków-Budapeszt 2008.

Gąsiorowski S., Towarzystwo Miłośników Historii i Literatury Karaimskiej w Wilnie i jego członkowie w latach 1932-1939 [w:] Karaj kiuńlari. Dziedzictwo narodu karaimskiego we współczesnej Europie, red. M. Abkowicz, H. Jankowski, współp. I. Jaroszyńska, Wrocław 2004, s. 71-83.

Helsztyński S., Hulewicz Witold (1895-1941) [w:] Polski Stownik Biograficzny, t. 10, Wrocław-Warszawa-Kraków 1962-1964, s. 96-97.

Hernik J., Wileńskie Środy Literackie, „Akcent. Literatura i Sztuka” R. 11, 1990, nr 1/2, s. 348-352.

Hernik Spalińska J., Wileńskie Środy Literackie (1927-1939), Warszawa 1998.

Kosman M., Radio Wileńskie i jego miejsce w kulturze Kresów Pótnocno-Wschodnich Polski międzywojennej, „Z Dziejów Polskiej Radiofonii” 2005/2006, nr 2, s. 154-155.

Kowalski T., Karaimische Texte im Dialekt von Troki. Teksty karaimskie $w$ narzeczu trockim, Kraków 1929 (Prace Komisji Orjentalistycznej Polskiej Akademii Umiejętności; 11).

Kowalski T., Pieśni obrzędowe w narzeczu Karaimów z Trok, „Rocznik Orientalistyczny” 1925, nr 3, s. 216-254.

Kwiatkowski M.J., Narodziny polskiego radia. Radiofonia w Polsce w latach 1918-1929, Warszawa 1972.

Németh M., Zwięzła gramatyka języka zachodniokaraimskiego z ćwiczeniami, Poznań 2011.

Paszkiewicz M., Piotrowicz Wiktor (1900-1954) [w:] Polski Stownik Biograficzny, t. 26, Wrocław 1981, s. 453-454.

Pawelec M., Płomień zgast przedwcześnie. Lidia Karakasz-Szole (1896-1943), „Awazymyz. Pismo Historyczno-Społeczno-Kulturalne Karaimów” 2011, nr 1 (30), s. 12-14.

Sulimowicz A., Hazzan, poeta, ttumacz. W 70. rocznicé śmierci Józefa Lobanosa (1880 1947), „Awazymyz. Pismo Historyczno-Społeczno-Kulturalne Karaimów” 2017, nr 3 (56), s. 9.

Wróblewska U., Działalność kulturalno-oświatowa Karaimów w Drugiej Rzeczypospolitej, Białystok 2015.

[Zajączkowski A.] I.-ski, Karaimskie kotysanki. (Z cyklu „O Karaimskiej Poezji Ludowej”), „Myśl Karaimska” R. 2, 1925, z. 2, s. 5-10.

Zajączkowski W., Łobanos Józef (1878-1947) [w:] Polski Stownik Biograficzny, t. 18, Wrocław-Warszawa-Kraków 1973, s. 369. 


\section{ANEKS ŹRÓDŁOWY}

Aneks składa się z dwóch części. W pierwszej zestawiono siedemnaście tekstów karaimskich piosenek, z których przynajmniej kilkanaście mogło być zaprezentowanych na Karaimskiej Środzie Literackiej w Wilnie w 1932 roku. Są to: Czubuk, Üwlariniź, Gidin buluttar gidin, Ycz karanfil aszładym, Inkermanda, Demerdziler, Fykyrynyn turkysy, Dülberin turkysy, Kelin awasy, Kielin awasy (dost kyzłar jyrtajtar), Eki-de kezin, Szarduwan (sewincz czeszmesy), Szerbiet (nedawanyn jasty künlarinde jyrtahan tirki), Kaleden-kelee, Achszam ołdy kün satdy ekindige, Dżankoz-golowa, Karasywnyn dört koszesy. Dwie pierwsze z podanych piosenek zostały pierwotnie zaopatrzone na maszynopisie w tłumaczenie na język polski, pisane odręcznie ołówkiem. W części drugiej znajdują się dwa skany. Na pierwszym widnieje spisany odręcznie przez Seraja Szapszała, hachana Karaimów II Rzeczypospolitej, tekst piosenki Czipiim, zapisany grażdanką, na drugim zaś nuty i tekst piosenki Irakdan, również grażdanką, autograf Walentyny Sulimowcz. Słowa piosenki: J.E. Duwan-Torcow, muzyka: E.M. Rofe. (Źródło: Nuty i teksty, Archiwum Józefa Sulimowicza, sygn. JSul. II.233).

\section{Część I}

\section{1) Czubuk}

Czubuk sieniń tel mienim

Siuwiarimsiń sień mienim

Jatłar nie ajtsa ajtsyn

Siuwiarimsiń sień mienim

Jatłar nie ajtsa ajtsyn

Siuwiarimsiń sień mienim.

Suw kielir jakar kietiar

Juriagim janar kietiar

Nie kutsuz bir dostum bar ekień

Bir kieczia konar kietiar

Nie kutsuz bir dostum bar ekień

Bir kieczia konar kietiar

\section{1) Smyczek [wersja polska]}

Drewno od smyczka twoje.

Włos zaś mój

Ukochana tyś moja

Obcy niech mówią co chcą 
Ty jesteś moją ukochaną

Obcy niech mówią co chcą

Wody poczną ciec

Śnieg roztaje

Serce moje rozpromieni się, za[...]

Mój duch jest nieszczęśliwy

Jedną noc przenocuję i odjadę

\section{2) Üwlariniź}

Uwlariniź jokcharda czykchałmyjmyn ałaj (2 razy)

Bir tiusiuńdiań biermiasień dżurałmyjmyn ałaj

Ałaj meken, szułaj miken, szojły meken ałaj

Dżergia dżatyp dżer tyrmałap dżyłał meken ałaj.

Kołundahy juziugiuj kałaj meken ałaj (2 razy)

Her bir jerdia tabjatyn mundaj meken ałaj

Ałaj meken szułaj meken, szojły meken ałaj

Dżergia dżatyp dżer tyrmałar dżurał meken ałaj.

\section{2) Wasz dom [wersja polska]}

Domy wasze wysoko zbudowane, nie mogę do nich dostać się.

Jeśli nie dasz mi coś na pamiątkę, nie zaznam spokoju.

Pierścionek na ręku twoim, czy nie z ołowiu.

$[\ldots]$

\section{3) Gidin bułutlar gidin}

Gidin bułutłar gidin

Dostuma sielan edin

Dost jukuda esia, oj doj aman

Jukusun sejran edin.

Szu gielen kajyk-mydyr?

Szu kyz maja łajyk-mydyr?

Dostum eller kuczhynda, oj doj aman

Jyłasam ujatymydyr? 


\section{4) Ycz karanfil aszladym}

Ycz karanfyl aszładym

Ałma suwyna taszładym

Dżandan sewgen jaremy

Ellere bakyszładym

Jar, jar, jar, aman (da)

Jar sewdaszy pek jaman

Karanfil kurutmadym

Men senni unutmadym

Xatirini czok sajdym

Ystine jar tutmadym

Jar, jar, jar, aman (da)

Jar sewdaszy pek jaman

Karanfilsin tadżymsyn

Tammam menim arcymsyn

Kojma meni dertlere

Men elirsem açyrsyn

Jar, jar, jar, aman (da)

Jar sewdaszy pek jaman

Jaszil kijmek pek gyzel

Ał bazardan, ej gyzel

Mewlam senni sakłasyn

Kez nazardan ej gyzel

Jar, jar, jar, aman (da)

Jar sewdaszy pek jaman

Kitdim kazanamadym

Keldim ewlenalmadym

Sziszib kałsyn bejle kar

Bu jyłda kałdym men nekar

Jar, jar, jar, aman (da)

Jar sewdaszy pek jaman

\section{5) Inkermanda}

Inkermanda tasz jukladim, gemim tołmady Szu jaszłychta bir jar sewdim, menim ołmady

Gel, gel, gel aman, aman ałajym seni

Eger kysmetim ołursa ałajym seni 
Men urusztan üwgia kajttym, chałym sałprady Troch szaharda bir kyz sewdim, atá bermiadi

Gel, gel, gel aman, aman ałajym seni

Eger kysmetim ołursa ałajym seni

Galwa giolgia awny sałdym, karmach üziuldiu Igit bojdachny sukłandym, mendian oł kiuldiu Gel, gel, gel aman, aman, kuczajym seni Nasz-jazyszym ma onarsa, erlarmiń seni

\section{6) Demerdżiler}

Demerdżiler demir doker tuncz ołyr, tuncz ołyr.

Sewib saib ajryłmasy, giecz ołyr.

Ach bejim aman giecz ołyr

Men kietersem senin chałyn nidże ołyr, nidże ołyr, Bülbül dałdan dżilber jardan ajryłmar

Ach bejim aman, ajryłmaz

Ajryłyb da jat ellerde chorłanmaz

Ach beji aman, chorłanmaz.

\section{7) Fykyrynyn turkysy}

Bir kałpahym bar baszymda czatłak-patłak

Bir janysy Dżygit szorbadżydan kełsyn mutłak

Syrtymdahy czekmenym szałach szułłak

Suwuktan üszüp oładżakym woła biła

Üstumdegi kaftanym jyrtyk-myrtyk

Bir janysyn kijsem dżursem kertyk-kurtuk

Arkamdahy kolegim eski-uski

Czok wachyta degiszmedym kokur-müski

Belimdegi kuszagym saczak-suczak

Kyzłar körse kaczahaj kosze-budżak

Ajahymda karewle kosze-budżak

Tabanymdan sez czykmaj juryszym muszuk 
Szałwarymnyn parczasy czuszup kałdy

Iczeklirmi bewle deret szasztym kałdym.

Dżebimdegi bosz kese kufły-mufły

Ben garypyn sorsrsanys juregim kapły

Uszte hałym uszte czułum, napajym

Sawłuk łen kałynys dżemat sobesge ketem.

\section{8) Dülberin turkysy}

Bojn senyn bek güzel selbi kibik

Belin senin bek indże fidan kibik

Swczcziklerin sim sija kunduz kubuk

Manłajczyhyn jyłtraj jyłdyz kibik

Kaszczykłaryn czyzyłhan kalem kibik

Burunczyhyn ufaczyk bedem kibik

Közczykłeryn köm-kökczik zümrüd kibik

Tyszczekłeryn bib-bijaz kar-süt kibik

Janakłaryn aczyłhan gułłer kibik

Ne chosz senyn cziszczegin kajmak kibik

Ahyzczehyn ufaczyk ojmak kibik

Datły senyn cziszczigin kajmak kibik

Barmachłaryn indżeczin kamysz kibik

Tyrnakłaryn jyłtraj kumusz kibik

Juriwiszin bek dülber toreler kibik

Wakyt sana bachta bersin dülberisin-dülberim.

\section{9) Kelin awasy}

Acztyn bachczyn kapysyn

Ałdym harpus jar-jar

Kysczyhym ketip paradyr

Kałdym janhys jar-jar

Lege legenkil tektim

Pba bołsyn jar-jar

Uzak erge kyz bermek 
Tobe bołsyn jar-jar

Kara syjyrnym münüzün

Kajyrmanyz jar-jar

Anasyndan bałasyn

Ajyrmasyn jar-jar

Kara syjyr münüzün

Kajyrdyłar jar-jar

Ben harypyn kysczyhyndan

Ajyrdyłar jar-jar

10) Kielin awasy (dost kyzłar jyrłajłar)

Kelene bak, kalene

Ał kyna jakmysz eline

Duszmusz eller tiline

Ahłama kelin, jasz kelin

Kelinin kijdyhy atłas

Atłaza ineler batmaz

Kijuw ałłachtan korkymas

Ahłama kelin, jasz kelin

Kelinin seczy tarałyr

Ał kynałar jahyłyr

Ałtyn indzi dołanar

Ahłama kelin, jasz kelin

\section{1) Eki-de kezin}

Ekid-de kezin eki ełmaz

Myndan güzel kasz ołmas

Seczlerin ziften kara

Łafłaryn juz bin para

Karszydan gördöm seni

Ał gülum Sandym seni

Kokłamaja kijmadym

Ellere werdim seny

Akilin ołsyn-ołmasyn

Tek dżebin para toły ołsyn

Bar baszta para kazan

Parasyz ołmaz nyszan 
By sezler bana olim

Nas etme bana gülum

Mał dżan elina kurban

Keri etme sen gülum

\section{2) Szarduwan (sewincz czeszmesy)}

Szarduwan kutty ołsyn

Czewresy gułden tołsyn

Szarduwanyn jasatkanyn

Omiri uzak ołsyn

Kelin amama keldi

Dostłar czewrejyp ałdy

Szarduwanłar aczyłdy

Kelin amama duszty

Biz kelinini ozharyrmyz

Szarduwanłaryn kaparmyz

Omiri uzak ołsyn

Ajahy ohyr ołsyn

\section{3) Szerbiet (nedawanyn jasły künlarinde jyrłahan tirki)}

Szerbiet baszy budur achyr zeman

Bu dunje kümge kałyr emen bizge

Kałmasyn Dayd-ohły Sulejmanha

Ömirler bek kyskadyr

Bu dunjede.

Ach anam, dżanym anam, kozim anam.

Dünjede ne müszkülder ögej anam

Gendi ohłyna töszar

Bastyn dij.

Gendi ohłyn asz piszirir

Esyn dij

Ben harybe zeer katar

Ołsin dij

Ach anam, dżanym anam, kozim anam

Dunjede bek jamandyr ögej ana. 


\section{4) Kaleden-kelee}

Kalenden kaleie

Szaan uczurdym

Ach ilen wach ilen

Ömirim geczirdim

Bir dülber ilen

Wakyt keczirdim

Ewle ołyr bewle ołyr

Dülberim ały

Dżülbesy czok ołyr bazy dülberin

Kalenin kałysy demir dügülmi

Demiri irtken komiri dügülmi

Sewdegin len jaszayk omir dügülmi

Ewle ołyr bewle ołyr dülberin ały

Dżülbesi czok ołyr bazy dülberin

Kalenin artynda ben dasz ajm

Jałynhyz gezene ben esz ołajm

Sewer dinderime

Jołdasz ołajm

Ewle ołyr bewle ołyr dülberin ały

Dżülbesy czok ołyr bazy dülberin.

\section{5) Achszam ołdy kün sałdy ekindige}

Achszam ołdy kün sałdy ekindige

Babam meny weredżek oła efendege

Babam wersede mem barmam efendege

Czym sajłap bararym

Anam benim karnym acz

Ber kałakaj

Sem meny weredżeksyn

Tuł akajha

Sen bersende ben barmam

Tuł akajha

Ozim sajłap bararmyn

Jasz igitke 
Papazłaryn, mołłałaryn

Iszi bitti

Kawesinin tütünine

Oty sendi

Karszydan kelir bir kajk

Karajm ony, bakajm

Iczinde igit ołmasa

Ateszlere jakajm

Syry syra maszyna

Keldim on-jedy jaszyn

Sajłap sajłap bardżakim

Tek karajym jaszyna.

\section{6) Dżankoz-gołowa}

Azbarymda dut terek

Japrakłary tegerek

Dżankoz gaława oładżak

Bizge turszu ne kerek

Szamdana mumaary dikildi

Derżana atłar jyhyłdy

Dżankoz gaława ołdyhy ilen

Turszunyn beli bukułdy

Sary papucz sary mest

Kijmemisin turszu

Bu szejlerin sen kōrip

Küjmemisin turszu

Azbarymda dut terek

Japrakłary tögerek

Dżankoz gaława ołhanson

Sasyk turszu ne kerek.

\section{7) Karasywnyn dört koszesy}

Karasywnyn dört koszesy

Waj czardahy dympyłdaj

Ozyde kyszy begenmes

Waj kajdahy dympyłdaj 
Aj katynda bir jyłdyz

Aj bałasy dympyłdaj

Ałtyn testensyn uczer

Baj bałasy dympyłdaj

Eltek czeltek kul dahła

Mangał masza

Ne dep ejtyn bu łafny

Sen köp jasza.

Anap kyrnynyn artynda

Kün kausza

Szu zenginler jurgende

Er majsza.

\section{Część II}

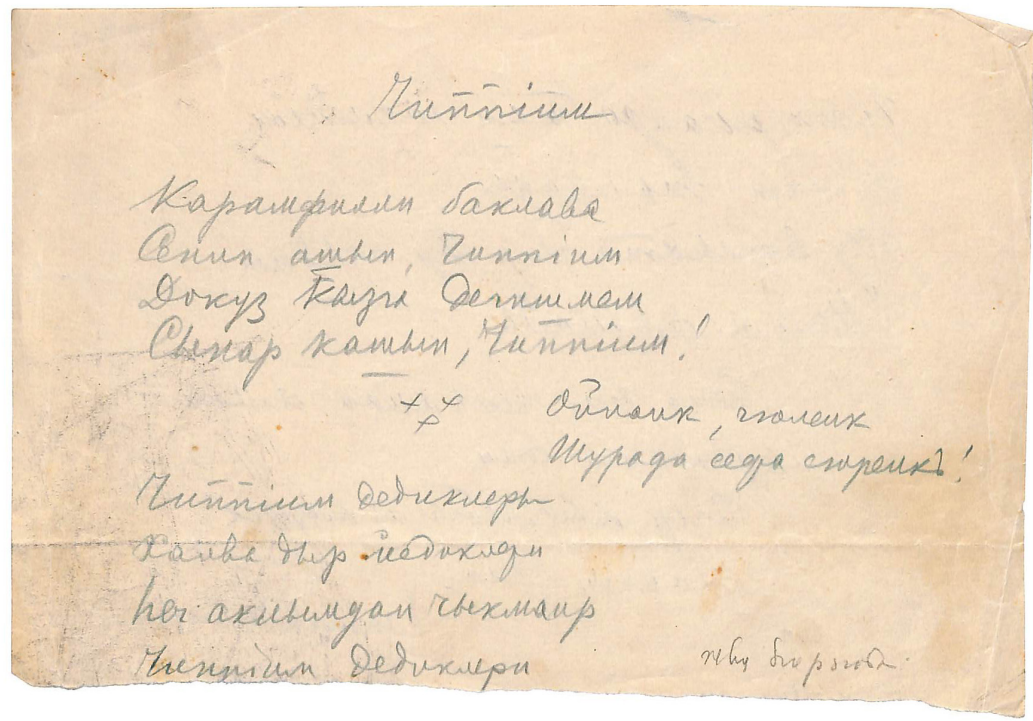

Ilustracja 1. Tekst piosenki Czipiim zapisany grażdanką przez Seraja Szapszała, hachana Karaimów II Rzeczypospolitej

Źródło: Nuty i teksty, Archiwum Józefa Sulimowicza, sygn. JSul. II.233. 


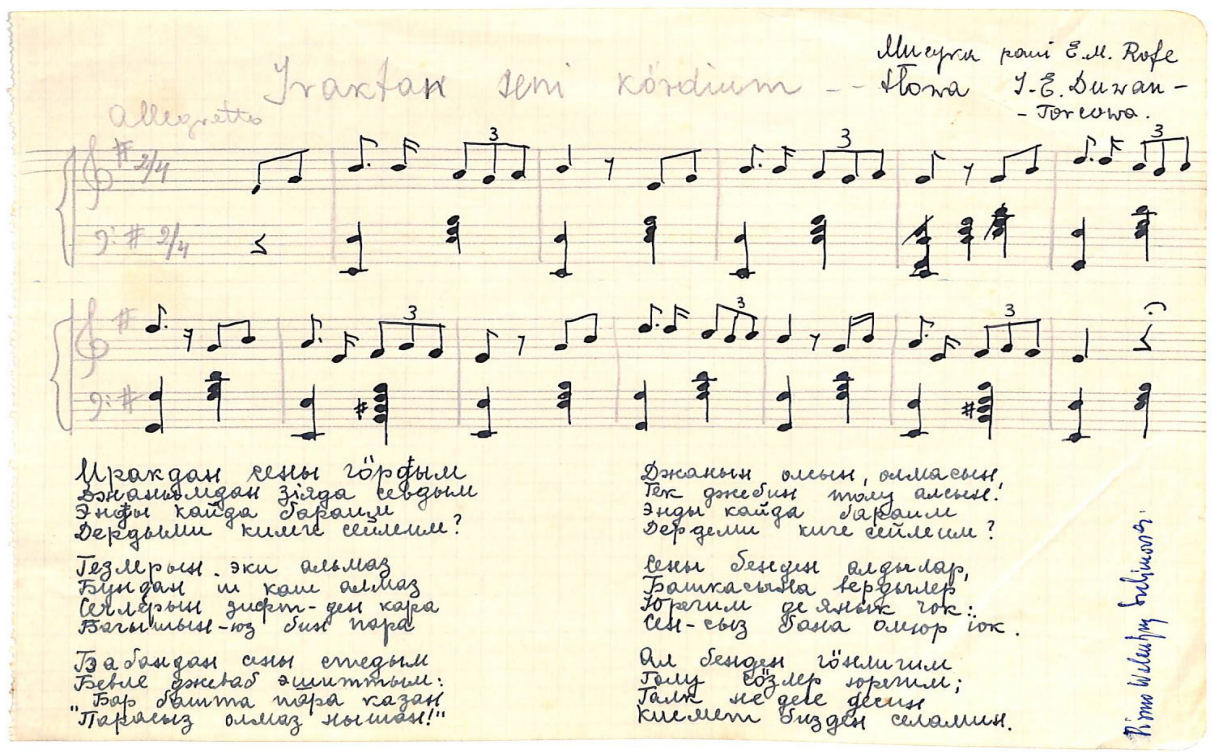

Ilustracja 2. Nuty oraz tekst piosenki Irakdan, zapisane grażdanką przez Walentynę Sulimowcz. Słowa piosenki: J.E. Duwan-Torcow, muzyka: E.M. Rofe

Źródło: Nuty i teksty, Archiwum Józefa Sulimowicza, sygn. JSul. II.233. 